\title{
PENAFSIRAN HAMKA TENTANG AYAT KEMAJEMUKAN DALAM TAFSIR AL-AZHAR
}

\author{
Moh Mufid Muwaffaq \\ Universitas Islam Negeri Sunan Kalijaga, Yogyakarta \\ pondokgue@gmail.com
}

\begin{abstract}
Plurality is often deemed as something natural that may become a basis for unity. In Indonesia, Muslims' thought on the issue has played an instrumental role in organizing the plurality. This article displays the stance of Buya Hamka, one of the most important figures of modernist camp of Muslims in the early stage after Indonesia's independency, on the issue of plurality by delving into Hamka's Tafsir al-Azhar. Hamka points out that a Muslim ought to focus on whatsoever lessons they got from others, rather than differences that may trigger social conflict. Yet when it comes to religious plurality, Hamka shows a sort of harsh stance particularly against the Christians. He mentions some aspects he considers theologically incorrect. In doing so, Hamka alludes to many social contexts he lives in, including the practice of endogamy conducted by Arab community on which he criticizes quite loud. The very character echoes the argument of scholars studying tafsirs circulating in Indonesia.
\end{abstract}

Keywords: Hamka, Tafsir Al-Az̧ar, plurality.

Abstrak: Kemajemukan dalam aspek apapun adalah hal alamiah yang bisa menjadi pilar persatuan. Dalam konteks Indonesia, sikap Muslim terhadap kemajemukan menentukan pola pengelolaan terhadapnya. Tulisan ini mengungkap sikap Buya Hamka, salah satu tokoh Muslim modernis penting di awal kemerdekaan Indonesia, terhadap isu pluralitas melalui tafsir yang beliau tulis, Tafsir al-Azhar. Dalam tafsir ini Hamka menjelaskan bahwa seorang Muslim harus menyikapi kemajemukan manusia (dalam hal ras, suku, bahasa, dan semacamnya) dengan fokus pada persamaan dan pelajaran yang bisa didapat, bukan pada perbedaan yang akan memicu konflik. Namun ketika berurusan dengan kemajemukan beragama, Hamka menunjukkan sikap yang keras dan tegas terutama pada umat Kristiani. Ia menyebut beberapa hal yang menurutnya adalah kesalahan teologis mereka. Dalam setiap penjelasannya, Hamka menyinggung secara intens konteks sosial yang dia hadapi, termasuk tradisi endogami komunitas Arab yang dia kritisi cukup keras. Karakter ini sesuai dengan apa yang telah diungkap oleh para sarjana yang mengkaji khazanah tafsir Indonesia.

Kata kunci: Hamka, Tafsir Al-Az̧ar, kemajemukan. 


\section{Pendahuluan}

Kemajemukan merupakan hal yang tidak bisa dipisahkan dari kehidupan manusia. Indonesia sendiri merupakan sebuah negara yang bisa dijadikan sebuah contoh dari kemajemukan itu sendiri. Setidaknya, hampir 500 suku yang tersebar dari Sabang sampai Merauke. Kemajemukan ini ibarat pisau bermata dua, di satu sisi bisa membawa berkah, namun di sisi lain bisa sekaligus membawa bencana. Keduanya sangat bergantung pada bagaimana cara bangsa Indonesia menyikapi kemajemukan itu. Namun, mengingat mayoritas (lebih dari 85\%) penduduk Indonesia adalah Muslim, maka sikap dan cara pandang umat Islam terhadap kemajemukan akan memiliki dampak yang signifikan bagi bangsa Indonesia secara keseluruhan. ${ }^{1}$ Pengetahuan keagamaan, termasuk di dalamnya tafsir, baik yang ditulis oleh ulama Timur Tengah maupun Nusantara tentu memiliki peran penting dalam membentuk sikap dan cara pandang tersebut.

Khazanah penulisan Tafsir Alquran yang awalnya terpusat di wilayah Timur Tengah dan Timur Dekat mulai diwarnai oleh karya ulama Indonesia sejak abad ke-17. Para sarjana bersepakat bahwa tafsir ulama Indonesia tertua yang terekam sampai saat ini adalah Tarjumān al-Mustafìd karya 'Abd al-Rauf al-Singkili yang ditulis menggunakan aksara Arab Melayu. Tafsir inilah yang kemudian menjadi embrio penulisan tafsir Alquran di Asia Tenggara. Menyusul al-Singkili adalah Shaykh Nawawi al-Bantāni dengan Tafsìr Marăḥ. Labid atau dikenal juga dengan nama Tafsir al-Munir yang pertama kali dicetak di Kairo pada tahun 1887 dengan menggunakan Bahasa Arab. ${ }^{2}$

Pasca munculnya dua tafsir di atas, tafsir-tafsir di Indonesia lantas bermunculan, baik yang ditulis oleh ulama secara independen maupun secara resmi oleh pemerintah. ${ }^{3}$ Dari banyak tafsir yang muncul di Indonesia, salah satu kitab tafsir yang menarik untuk dibahas adalah

\footnotetext{
1 Nurrohman, "Islam dan Kemajemukan di Indonesia: Upaya Menjadikan NilaiNilai Yang Menjunjung Tinggi Kemajemukan Dalam Islam Sebagai Kekuatan Positif Bagi Perkembangan Demokrasi", dalam Jurnal Asy-Syari'ah Vol. 17 No. 3 (2015), 227.

2 Hasani Ahmad Said, "Mengenal Tafsir Nusantara: Melacak Mata Rantai Tafsir Dari Indonesia, Malaysia, Thailand, Singapura Hingga Brunei Darussalam", dalam Jurnal Refleksi, Vol. 16, No. 2 (2017), 215.

${ }^{3}$ M. Quraish Shihab dalam pengantar buku Taufik Adnan Amal, Rekonstruksi Sejarah Al-Qur'an (Jakarta: Pustaka al-Fabets, 2005), vi. Dalam bentuk karya Tim Penerjemah al-Quran Depag RI, Al-Quran dan Terjemahnya (Jakarta: Yayasan Penyelenggara Penerjemah/penafsiran Al-Quran, Depag RI, 1975).
} 
Tafsir al-Azhar karya Haji Abdul Malik Karim Amrullah atau lebih dikenal dengan nama Buya Hamka. Tafsir ini menarik karena dalam setiap penafsirannya, tidak jarang mufasir memberikan porsi yang cukup besar terhadap persoalan-persoalan, peristiwa, dan sejarah kontemporer (waktu hidup), baik yang terjadi secara global maupun yang terjadi pada pribadinya sendiri. Selain itu, Hamka dikenal dengan fatwanya yang cukup keras tentang hubungan Muslim dan pemeluk agama lain, terutama umat Kristiani. Untuk itu, artikel ini hendak melihat bagaimana pandangan Hamka terhadap ayat-ayat kemajemukan serta konteks sosio-politik yang melatari kemunculan pandangan Hamka terkait dengan hal itu. Beberapa ayat yang menjadi sampling dalam pembahasan ini adalah QS. al-Mā'idah [5]: 44, 46-48, QS. al-Rūm [30]: 22, ${ }^{4}$ dan al-Hujurāt [49]: 13.

\section{Haji Abdul Malik Karim Amrullah dan Tafsir al-Azhar}

Haji Abdul Malik Karim Amrullah atau lebih sering dipanggil dengan nama Buya Hamka merupakan salah satu ulama yang berasal dari Kampung Tanah Sirah, Negeri Sungai Batang di tepi Danau Maninjau, Minangkabau, Padang, Sumatera Barat. Hamka adalah putera pertama dari pasangan Haji Abdul Karim Amrullah ${ }^{6}$ dan Siti Safiyah Tanjung binti Haji Zakaria. Hamka lahir pada hari Minggu 13 Muharram atau 16 Februari 1908 M.

4 Pemilihan ayat-ayat ini merujuk pada pemilihan Muḥammad 'Imārah ketika membahas tentang pluralitas. Lihat Muhammad 'Imārah, Islam dan Pluralitas: Perbedaan dan Kemajemukan dalam Bingkai Persatuan, terj. Abdul Hayyie al-Kattanie (Jakarta: Gema Insani Press, 1997), 145-207. Penambahan QS. al-Hujurāt dalam daftar ini dilakukan karena sikap Hamka terhadap manusia secara umum belum terlihat dalam al-Rūm, seperti yang akan dijelaskan lebih lanjut di belakang.

${ }^{5}$ Nama panggilan HAMKA merupakan akronim dari nama lengkapnya yaitu Haji Abdul Malik bin Abdul Karim Amrullah. Lihat Hamka, "Nama Saya: Hamka," dalam Nasir Tamara (dkk.) (ed.), Hamka di Mata Hati Umat (Jakarta: Sinar Harapan 1983), 51.

${ }^{6}$ Haji Abdul Karim Amrullah biasa dipanggil dengan sebutan Haji Rasul merupakan seorang ulama yang dikenal sebagai tokoh gerakan modernisme Islam (Kaum Muda) di Minangkabau. Lihat, Alfian, "Hamka dan Anaknya" dalam Solichin Salam (dkk.)(ed.), Kenang-Kenagnan 70 Tahun Buya Hamka (Jakarta: Yayasan Nurul Islam, 1978), 125. Haji Rasul merupakan putra dari seorang ulama besar bernama Shaykh Muhammad Amrullah yang dikenal sebagai orang alim di zamannya. Hamka sejak kecil diharapkan menjadi ulama besar sebagai penerus ayah dan kakeknya tersebut. Lihat: Hamka, Tafsir al-Azhar, vol. 1 (Jakarta: Pustaka Panjimas, 1982), 5. 
Pada tahun 1916 ketika berusia delapan tahun, Hamka memulai pendidikan formal pertamanya di Sekolah Pagi selama dua tahun. Setelah itu Hamka masuk ke Madrasah Diniyah yang didirikan oleh Zainuddin Lebay el-Yunusi pada pagi hari, dan pada sore harinya di Madrasah Tawalib, sekolah modern Islam pertama di Indonesia. Ini dia lakukan selama dua tahun. Selanjutnya, Hamka menjalankan pendidikannya secara otodidak dengan melakukan perjalanan dari satu kota ke kota lainnya. ${ }^{7}$

Pada 1949 Hamka datang ke Jakarta untuk mengembangkan misi dakwahnya. Dalam beberapa tahun berikutnya dia menjalani karir di bidang jurnalistik, penulisan, politik, dan tentunya akademik. Hamka juga tercatat pernah mengajar di beberapa perguruan tinggi, seperti Universitas Islam Sumatera Utara (UISU), Perguruan Tinggi Agama Islam Negeri (PTAIN) Yogyakarta, Universitas Islam Jakarta dan Universitas Muslim Indonesia (UMI). ${ }^{8}$

Hamka pernah menjabat sebagai ketua Majelis Ulama Indonesia (1975-1981) dan mengeluarkan beberapa fatwa yang kontroversial. Salah satu yang paling dikenal adalah fatwa tentang haramnya mengikuti perayan 'Natal Bersama'. Dua bulan setelah Buya Hamka mengundurkan diri sebagai anggota MUI, tepatnya pada hari Jum'at tanggal 24 Juli 1981 atau 22 Ramadhan $1401 \mathrm{H}$, tokoh ulama asal Minangkabau tersebut wafat ${ }^{9}$ ketika menjalani perawatan intensif di Rumah Sakit Pusat Pertamina.

Meski disibukkan dengan berdakwah dan mengajar, Hamka tetap menyempatkan menuangkan ide-ide kreatifnya dalam bentuk tulisan. Karya yang dihasilkan pun tidak tertuju kepada satu disiplin ilmu saja, tetapi juga menjangkau berbagai disiplin ilmu seperti teologi, tasawuf, filsafat, pendidikan Islam, sejarah Islam, fiqih, sastra hingga tafsir. Dalam disiplin yang terakhir ini, karya beliau cukup fenomenal di kalangan masyarakat Muslim Indonesia. Tafsir tersebut diberi nama Tafsir al-Azhar. Tafsir ini pertama kali ditulis dalam bentuk uraian yang disampaikan beliau pada kuliah subuh secara rutin di Masjid Agung alAzhar. Kemudian tafsir ini berhasil ditulis secara utuh pada tahun

\footnotetext{
${ }^{7}$ Muklis, Inklusifisme Tafsir al-Azhar (Mataram: IAIN Mataram Press, 2004), 34-36.

8 Rusydi, Martabat dan Pribadi Buya Prof. Dr. Hamka (Jakarta: Pustaka Panjimas, 1983), 4-5.

9 Hamka mengalami serangan jantung yang mengharuskan beliau dirawat secara insentif di Rumah Sakit Pertamina dengan ditangani para dokter ahli. Namun pada hari ketujuh pada pukul 10:37 dengan dikelilingi anak-anak dan isterinya, Buya Hamka meninggal dunia. Lihat, Irfan Hamka, Ayah (Jakarta: Republika, 2016), 40.
} 
1964 di rumah tahanan politik Mega Bandung hingga dilakukan perbaikan ketika beliau dibebaskan oleh Orde Baru pada tanggal 21 Januari 1966. Tafsir ini akhirnya dapat diselesaikan pada bulan Agustus $1975 .{ }^{10}$

Tafsir al-Azhar merupakan sebuah tafsir yang mencerminkan watak dan ideologi Hamka secara dikenal sebagao orang yang tegas, lugas dan jelas. Beliau banyak membicarakan tentang karakter masyarakat dan sosio-kultural yang terjadi pada masa hidupnya. Penulisan Tafsir al-Az̧bar sendiri tidak lepas dari 20 tahun perjuangan. Hamka mampu merekam kehidupan dan sejarah sosio-politik umat Islam yang getir. Karya-karyanya dapat dikatakan sebagai upaya untuk menampakkan cita-citanya dalam menjelaskan kepada masyarakat tentang pentingnya dakwah di Indonesia. ${ }^{11}$

Penulisan Tafsir al-Azhar tidak jauh berbeda dengan kitab-kitab tafsir sebelumnya yang menggunakan metode taḅlilit ${ }^{2^{2}}$ dengan menerapkan sistematika tartib muş̧afi. Di antara hal-hal yang membuat buku ini berbeda adalah penekanannya terhadap penggunaan petunjuk Alquran dalam kehidupan umat Islam secara nyata. Hamka dengan cukup intens mengaitkan penafsiran ayat Alquran dengan sejarah dan

\footnotetext{
${ }^{10}$ Ratnah Umar, "Tafsir al-Azhar (Metode dan Corak penafsirannya)", dalam Jurnal al-Asas, Vol. III, No. 1 (2015), 22.

11 Avif Aliviyah, "Metode Penafsiran Buya Hamka dalam Tafsir al-Azhar", dalam Jurnal Ilmiah Ilmu Ushuluddin, Vol. 15, No.1 (2016), 28

12 Alfarmawi membagi metode tafsir menjadi empat macam. Pertama, taḥlili, yang disebut juga dengan metode tafsir Tajzi $i$, yakni menjelaskan kandungan Alquran dari bebagai aspek dengan memperhatikan runtutan ayat-ayat yang tercantum dalam musḥaf mulai dari kosakata, asbāb al-nu₹ūl, munāsabab dan lainnya. Kedua, tafsìr mawdūi, yang berawal dari adagium "biarkan Alquran berbicara dengan dirinya sendiri". Dalam metode ini seorang mufasir dituntut untuk menghimpun ayat-ayat terkait topik yang menjadi kajian penelitian, kemudian pada kegiatan penafsiran baru dilakukan sesuai dengan kaidah yang berlaku pada umumnya. Ketiga, tafsir ijmāti, yakni menafsirkan Alquran dengan global, tidak berpanjang lebar sebagaimana model tafsir taḅlili. Tafsir dengan metode ini tetap dilakukan dengan struktur musḥafi dengan penyajian bahasa yang ringkas dan sederhana, dengan tujuan dapat dibaca dengan mudah oleh khalayak umum. Keempat, tafsir dengan metode muqärin, yakni langkah-langkah menafsirkan Alquran dengan memperbandingkan sekelompok ayat yang terlihat bertentangan, atau ayat dengan hadis begitu juga memperbandingkan pendapat-pendapat para ulama mufasir dalam menafsirkan sebuah ayat namun dengan memperlihatkan letak perbedaan dari objek yang dibandingkan. Dari keempat metode diatas, metode pertama dan kedua merupakan metode yang lebih popular dikalangan para mufasir. Lihat 'Abd al-Hayy al-Farmāwi, Al-Bidayah $\bar{f} \bar{i}$ Tafsìr al-Mawdūì (Mesir: Al-Maktabat Al-Jumhūriyah, 1992), 22.
} 
peristiwa-peristiwa kontemporer ${ }^{13}$ baik yang terjadi secara global dalam rentang waktu tertentu atau hal-hal yang terjadi pada pribadi Hamka itu sendiri.

Howard M. Federspiel menuturkan dalam penelitiannya tentang tafsir Indonesia bahwa Tafsir al-Azhar memiliki ciri khas sebagaimana karya tafsir Indonesia yang lahir di era yang sama; menyajikan teks ayat Alquran dengan terjemahannya; memaparkan dan menjelaskan istilah-istilah agama yang menjadi bagian tertentu dari teks; menambahkan materi pendukung lain untuk membantu dan memudahkan pembaca dalam memahami maksud dan kandungan setiap ayat. ${ }^{14}$

Tafsir al-Az̧har terlihat dengan jelas bercorak adäbi ijtimà $\bar{\imath}$ atau memiliki corak sastra kemasyarakatan. Lebih jelasnya, tafsir dalam kategori ini menitikberatkan pada penjelasan ayat-ayat Alquran dari segi ketelitian redaksinya, kemudian menyusun kandungan Alquran dalam sebuah redaksi yang indah dengan menonjolkan aspek petunjuk Alquran bagi kehidupan, serta mengaitkan pengertian ayat-ayat dengan hukum alam (sunnat Allăh) yang berlaku dalam masyarakat. ${ }^{15}$ Akhirnya, dapat dikatakan bahwa Tafsir al-Azhar memiliki maksud dan tujuan untuk menghidupkan nilai-nilai Alquran dalam masyarakat Islam yang lebih nyata serta diimplementasikan dalam setiap tindakan. ${ }^{16}$

Dalam pembukaan tafsirnya, Hamka mengakui bahwa penulisan Tafsir al-Azhar sedikit banyak dipengaruhi dan diinspirasi dari metode dan alur Tafsir al-Manār karya Muhammad 'Abduh dan Rashìd Riḍā. Menurut Hamka, Tafsìr al-Manār sangat cocok dijadikan sebagai contoh tafsir di era modern. Ini dikarenakan dalam setiap penafsirannya Muhammad 'Abduh dan Rashìd Rị̣̄a tidak hanya menguraikan ayat-ayat Alquran dengan menggunakan hadis, fikih, sejarah dan lain sebagainya, tetapi juga menyesuaikan setiap ayat dalam Alquran dengan perkembangan politik dan kemasyarakatan yang sesuai dengan kondisi zaman dan waktu dimana tafsir tersebut ditulis. ${ }^{17}$

\footnotetext{
${ }^{13}$ Howard M Federspiel, Kajian-kajian al-Qur'an di Indonesia (Bandung: Mizan. 1996), 142.

${ }^{14}$ Ibid., 143.

15 Al-Farmāwi, Al-Bidāyah, 23-24.

${ }^{16}$ Husnul Hidayati, "Metodologi Tafsir Kontekstual Al-Azhar Karya Buya Hamka", dalam El-Umdah Jurnal Ilmu al-Quran dan Tafsir, Vol. 1, No. 1 (2018), 34-35.

${ }^{17}$ Hamka, Tafsir al-Az̧har, vol. 1, 41.
} 


\section{Penafsiran Hamka Terhadap Ayat Kemajemukan}

Kemajemukan manusia dalam konteks yang luas merupakan kajian yang tidak abstain dalam pembahasan Hamka. Ketika berbicara tentang ini, Hamka terlihat cukup netral dengan menyampaikan apa yang biasa kita dengar dari para mufasir pada umumnya. Ia mengatakan bahwa tujuan diciptakannya manusia dalam watak keberagaman ini adalah untuk saling mengenal dan berlomba dalam kebaikan, bukan mencari perbedaan dan menciptakan konflik atas dasar keberagaman tersebut. Pandangan ini tampak lebih jelas ketika Hamka menafsirkan surah al-Rūm [30]: 22.

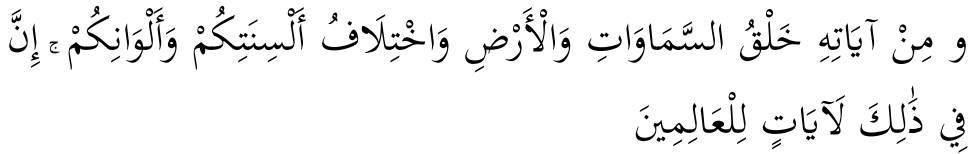

"Dan di antara tanda-tanda (kebesaran)-Nya ialah penciptaan langit dan bumi, perbedaan bahasamu dan warna kulitmu. Sungguh, pada yang demikian itu benar-benar terdapat tandatanda bagi orang-orang yang mengetahui."

Dalam menafsirkan ayat tersebut, Hamka menekankan bahwa keberagaman manusia dalam hal apapun harus dipandang sebagai bukti kekuasaan Allah. Hamka menganjurkan Muslim untuk menjadi apa yang disebut ayat ini sebagai 'álimin, orang-orang yang mengetahui. Caranya adalah dengan menyadari seluruh keberagaman yang ada dan merenungkannya. Di antara empat miliar penduduk dunia ini," 18 tentu kita akan sangat mudah menemukan miliaran perbedaan pula. Dalam konteks ini, Hamka mengajak pembaca untuk merenungkan keberagaman yang hadir di level global kemudian beranjak ke lingkungan yang lebih dekat dan personal. Ia menulis:

"Ada bahasa Inggris, ada bahasa Perancis, ada bahasa Jerman, ada bahasa Rusia dan berbagai bahasa lagi di Eropa Timur, dan ada bahasa Italia, ada bahasa Spanyol. Jangankan demikian, sedangkan di tanah air Indonesia, negara kepulauan ini saja, tidak kurang daripada 300 bahasa daerah, yang kalau tidaklah ada bahasa persatuan Indonesia, yang dahulunya bernama bahasa Melayu, yang jadi lingua franca yang mempersatukan pulau-pulau ini, alangkah sukarnya buat menjadi sebuah negara besar."19

Ada beberapa hal yang menarik untuk dibahas dari pernyataan Hamka tersebut. Beberapa negara yang dia sebutkan dalam pernyataan tersebut adalah negara-negara yang bertetangga dan

${ }^{18}$ Ibid., vol. 21, 88

${ }^{19}$ Ibid. 
termasuk dalam wilayah geografis benua Eropa. Negara-negara tersebut masih terhitung sebagai tetangga Belanda. Hanya satu negara yang berposisi cukup jauh di timur, Rusia, dan Hamka menjelaskan ketimuran Rusia ini dengan menyebut Eropa Timur. Tidak berlebihan jika kita boleh menduga bahwa Hamka mengetahui informasi tentang negara-negara ini dari orang-orang Eropa yang tentunya saat itu masih banyak tinggal di Indonesia, atau dari orang-orang Indonesia yang akrab dengan wilayah tersebut.

Penyebutan lingua franca dalam kutipan tersebut bisa dianggap sebagai indikasi bahwa Hamka adalah orang yang berpendidikan cukup tinggi. Istilah tersebut tidak hanya asing dalam kalangan studi Islam ala Timur Tengah yang berkembang di madrasah, tetapi asing pula bagi para pengkaji disiplin ilmu lain. Yang cukup akrab dengan terma tersebut adalah mereka yang bergelut dengan kajian sosial dan/atau kajian sejarah sosial. Dari sini kita bisa menduga bahwa lingkungan akademik Hamka merupakan lingkungan yang cukup 'elit'.

Dugaan ini diperkuat dengan penyebutan beberapa disiplin ilmu yang cukup spesifik dan asing bagi mereka yang berada di luar lingkungan akademik sekuler. Disiplin-disiplin ini Hamka sebutkan dalam bagian lain ketika dia masih menjelaskan ayat yang sama. Dia mengatakan

“... manusia mendirikan berbagai Universitas dengan berbagai Fakultas. Ilmu Alam yang meminta pengetahuan tentang bintangbintang di langit, ilmu bumi tempat kita berdiam. Sangat banyak ilmu yang timbul di atas permukaan bumi ini. Yang berkenaan dengan kemanusiaan saja berbagai cabang bahagiannya: Ethnologi, Antropologi, Sosiologi, Psychologi, Histori, Ilmu Pukrbakala (Archeolog $z$ ), Ekonomi, Politik dan Sosial. Belum tentang bumi itu sendiri dengan berbagai ragam ilmunya: Ilmu tumbuh-tumbuhan, ilmu pertambangan, ilmu berkebun, ilmu tentang hidup (Ilmu Hayat) yang mengenai manusia, binatang, serangga, ikan dan burung. Ilmu tentang lautan dengan berbagai ragamnya (Oceanolog $t)$. Dan semuanya itu bertali pula dengan ilmu alat penting sejak dari Ilmu Ukur, Ilmu Berhitung dan berbagai macam ilmu pasti yang akan membawa kepada teknologi." ${ }^{20}$

Seluruh keberagaman yang disebut Hamka tersebut sekali lagi hanya ditempatkan sebagai bahan renungan. Tujuan utama perenungan ini adalah untuk menjadi álimìn, 'orang-orang yang mengetahui'. Barangkali juga karena inilah Hamka begitu detail

${ }^{20}$ Ibid., 88-89. 
menyebutkan berbagai jenis ilmu. Namun perlu ditegaskan di sini bahwa dalam ayat ini tidak terlihat satu sikap yang lebih jelas untuk digunakan dalam bersosialisasi antar manusia, baik dari kelompok agama, budaya, atau identitas sosial lainnya. Sikap ini baru terlihat dalam tafsirnya terhadap Surat al-Hujurāt [49]: 13.

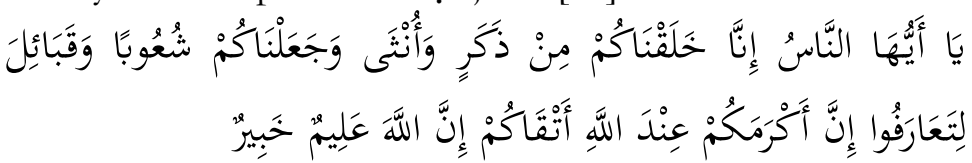

"Wahai manusia! Sungguh, Kami telah menciptakan kamu dari seorang laki-laki dan seorang perempuan, kemudian Kami jadikan kamu berbangsa-bangsa dan bersuku-suku agar kamu saling mengenal. Sesungguhnya yang paling mulia di antara kamu di sisi Allah ialah orang yang paling bertakwa. Sungguh, Allah Maha Mengetahui, Mahateliti."

Pada penjelasan ayat ini, Hamka menunjukkan sikap yang jelas terkait anjuran dan prinsip bagi seorang Muslim ketika bersama orang-orang dengan identitas lain. Pada intinya Hamka mengatakan bahwa manusia harusnya berinteraksi satu sama lain untuk saling mengenal sera mempelajari kebaikan di antara yang lain. Manusia bergaul supaya kenal mengenal, mencari pertalian dengan orang lain agar yang jauh menjadi dekat dan yang renggang menjadi karib." ${ }^{21}$ Ia memperingatkan pembacanya untuk tidak mencari-cari perbedaan yang kemudian akan menimbulkan perselisihan di antara mereka sendiri. Dengan cukup lugas Hamka memberikan satu saran tentang strategi yang dapat dilakukan untuk menciptakan persatuan antar umat manusia yakni mengenali bahwa mereka berasal dari garis keturunan yang sama. Ia Menegaskan:

"Seumpama kami orang tepi Danau Maninjau, umum rata menyebut bahwa asal kami datang dari Luhak Agam; dan Luhak Agam adalah berasal dari Pagarruyung. Menjadi kebiasaan pula menurut pepatah 'jika jauh mencari suku, jika dekat menjadi hindu'. Walaupun orang suku Tanjung datang dari negeri Tanjung Sani, lalu dia merantau ke Tapan Indrapura di Pesisir Selatan, atau ke Kampar daerah Riau, mulanya secara iseng-iseng orang dari Tanjung Sani tadi menanyakan kepada orang tepatannya di Indrapura atau Kampar tadi, apakah suku. Jika dijawab bahwa yang ditanyai itu adalah bersuku Tanjung, mereka pun mengaku bersaudara seketurunan. Kalau yang ditanyai menjawab bahwa sukunya ialah Jambak, misalnya, maka orang Tanjung dari Tanjung

${ }^{21}$ Ibid., vol. 26, 243-245 
Sani tadi menjawab dengan gembira bahwa orang suku Jambak adalah 'Bako' saya, artinya saudara dari pihak ayahnya. Dan kalau orang itu menjawab sukunya Guci, maka dengan gembira dia menjawab bahwa saya ini adalah menantu tuan-tuan, sebab isteri dan anak-anak saya adalah suku Guci. Demikianlah seterusnya ..."22

Yang menarik adalah bahwa Hamka menyebut konteks sosialnya yang sangat dekat dalam menjelaskan makna ini. Beberapa tempat dan identitas keluarga yang disebutkan oleh Hamka hanya familiar bagi orang yang tinggal di daerah yang bersangkutan. Pertautan dengan konteks sosial tidak hanya muncul dalam bagian ini. Hamka juga menyampaikan kritik yang cukup pedas pada tradisi endogami yang dibawa oleh komunitas keturunan Arab, seperti dalam pernyataannya:

"(S)eorang anak perempuan bangsa Syarifah, tidak boleh kawin dengan laki-laki yang bukan Sayid, walaupun laki-laki itu beragama yang baik dan berbudi yang terpuji." 23

Lanjutan dari kritik ini cukup keras untuk dilontarkan seorang pendakwah dalam sebuah kitab tafsir. Dalam kritiknya, Hamka memberikan perbandingan yang cukup ekstrem antara seorang pemuda keturunan sayid yang berbudi tidak terpuji dan pemuda nonsayid yang berbudi terpuji. Sayangnya belum ditemukan data yang lebih bisa menjelaskan keterkaitan Hamka dengan komunitas Arab tertentu. Meskipun begitu, ini menunjukkan sikap objektif Hamka dalam menilai dan memperjuangkan gagasannya terkait pentingnya memahami keragaman manusia. Pemahaman yang dilandaskan atas Alquran maupun konteks historis yang dekat dengannya, sebagai penulis tafsir.

Dalam bagian lain, Hamka menjelaskan pertautan sosial dalam dimensi berbeda. Kali ini Hamka berbicara tentang Barat dan berbagai gaya hidup yang dipraktikkan di sana. Ada dua hal tentang ini yang dibicarakan; pertama, berkaitan dengan kesombongan Hitler ketika berkata "Duitsschland ubber alles?" (Jerman di atas dari segala-galanya). Kedua, berkaitan dengan gaya hidup liberalis yang diasumsikan berlaku di Barat; tentang kebebasan bergaul dan melakukan hubungan seksual. Pandangan polemis tentang Barat ini selanjutnya terbias dalam pandangan Hamka tentang agama yang kemudian diidentikkan dengan Barat, yaitu Yahudi dan terutama Kristen. Bias ini dapat

\footnotetext{
22 Ibid.

${ }^{23}$ Ibid., 246-247.
} 
diperhatikan secara gamblang ketika Hamka menafsirkan ayat keberagaman agama, yaitu QS. al-Mā’idah [5]: 44 dan 46-48.

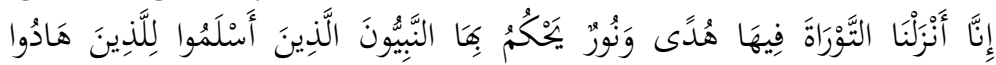

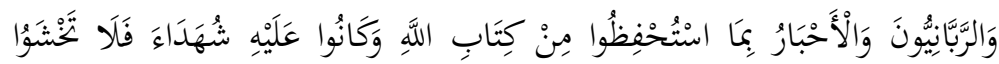

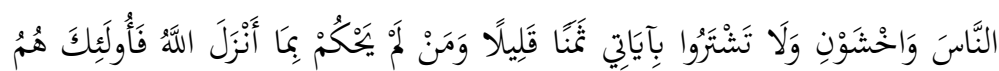

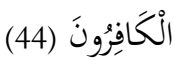

"Sungguh, Kami yang menurunkan Kitab Taurat; di dalamnya (ada) petunjuk dan cahaya. Yang dengan Kitab itu para nabi yang berserah diri kepada Allah memberi putusan atas perkara orang Yahudi, demikian juga para ulama dan pendeta-pendeta mereka, sebab mereka diperintahkan memelihara kitab-kitab Allah dan mereka menjadi saksi terhadapnya. Karena itu janganlah kamu takut kepada manusia, (tetapi) takutlah kepada-Ku. Dan janganlah kamu jual ayat-ayat-Ku dengan harga murah. Barangsiapa tidak memutuskan dengan apa yang diturunkan Allah, maka mereka itulah orang-orang kafir."

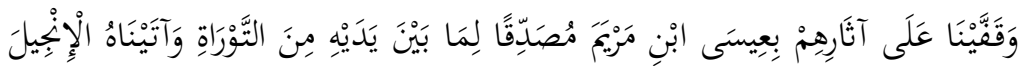

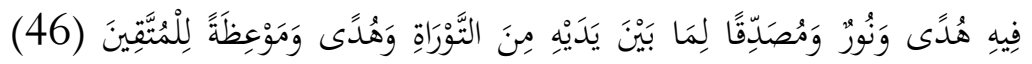

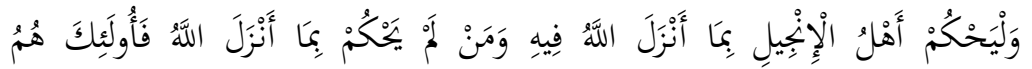

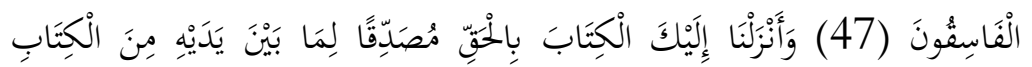

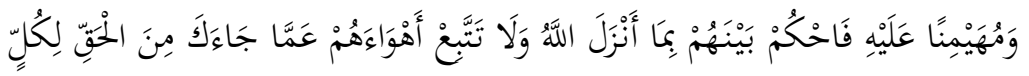

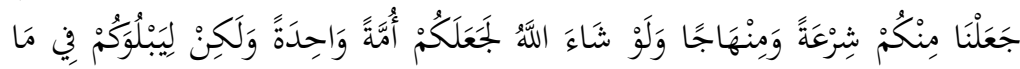

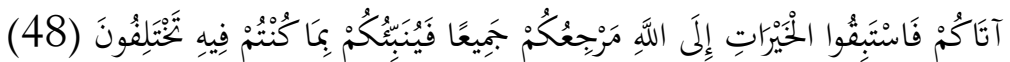

"Dan Kami teruskan jejak mereka dengan mengutus Isa putra Maryam, membenarkan Kitab yang sebelumnya, yaitu Taurat. Dan Kami menurunkan Injil kepadanya, di dalamnya terdapat petunjuk dan cahaya, dan membenarkan Kitab yang sebelumnya yaitu Taurat, dan sebagai petunjuk serta pengajaran untuk orang-orang yang bertakwa. Dan hendaklah pengikut Injil memutuskan perkara menurut apa yang diturunkan Allah di dalamnya. Barangsiapa tidak memutuskan perkara menurut apa yang diturunkan Allah, maka mereka itulah orang-orang fasik. Dan Kami telah menurunkan Kitab (Al-Qur'an) kepadamu (Muhammad) dengan membawa kebenaran, yang membenarkan kitab-kitab yang diturunkan sebelumnya dan 
menjaganya, maka putuskanlah perkara mereka menurut apa yang diturunkan Allah dan janganlah engkau mengikuti keinginan mereka dengan meninggalkan kebenaran yang telah datang kepadamu. Untuk setiap umat di antara kamu, Kami berikan aturan dan jalan yang terang. Kalau Allah menghendaki, niscaya kamu dijadikan-Nya satu umat (saja), tetapi Allah hendak menguji kamu terhadap karunia yang telah diberikan-Nya kepadamu, maka berlomba-lombalah berbuat kebajikan. Hanya kepada Allah kamu semua kembali, lalu diberitahukan-Nya kepadamu terhadap apa yang dahulu kamu perselisihkan."

Penjelasan Hamka terhadap ayat-ayat di atas cukup panjang dan tampak mengulang-ulang pada beberapa poin. Secara garis besar, Hamka mengatakan bahwa inti ajaran dari ketiga agama samawi atau yang juga dikenal dengan agama abrahamik adalah tauhid dan ke-Esaan Tuhan. Ketiganya memiliki syariat yang berbeda karena memang itu didesain sedemikian rupa agar sesuai dengan konteks masingmasing. Dengan mengutarakan ini, Hamka mengatakan bahwa dua agama sebelumnya telah mengalami perubahan yang cukup serius sehingga tidak lagi bisa diikuti begitu saja. ${ }^{24}$

Terkait hal tersebut Hamka menjelaskan bahwa Nabi Isa turun tidak untuk serta merta menghapus syariat yang dibawa oleh Musa dan Taurat untuk Bangsa Yahudi. Hamka kemudian memberikan beberapa bukti dimana Isa memberikan putusan yang sesuai dengan hukum Taurat. Hamka lantas mengatakan dengan tegas bahwa trinitas adalah sebuah kepercayaan yang ditambahkan belakangan oleh Paulus $^{25}$. Dalam konteks ini Hamka dengan spesifik mengatakan nama Paulus sebagai pihak yang menyusupkan hukum-hukum Yunani dan Romawi ke dalam Injil. Hamka membawa pembaca pada argumennya ini dengan menelusuri perkataan Yesus/Isa sendiri dalam tiga Injil sebelumnya: Matius, Markus, dan Lukas. Tidak tanggung-tanggung, dia memberikan kutipan langsung dari tiga injil tersebut. Beberapa di antaranya adalah:

"Nyahlah engkau dari sini, hai Iblis. Karena telah tersurat. Hendaklah engkau menyembah Allah Tuhanmu, dan beribadat hanya kepadaNya saja." (Lukas 4: 8)

Jawab Yesus kepadanya: "Apakah sebabnya kaku katakan aku ini baik? Seorangpun tiada yang baik, hanya satu, yaitu Allah." (Markus $10-17: 18)^{26}$

\footnotetext{
${ }^{24}$ Ibid. Vol. 6, 255

25 Ibid, 256.

${ }^{26}$ Ibid.
} 
Dengan menyertakan kutipan-kutipan ini Hamka ingin mengatakan bahwa Isa sendiri menyeru pada Bangsa Israel untuk menyembah Allah. Dalam banyak kutipan lain Hamka mengatakan bahwa umat Kristiani telah salah memahami ungkapan anak Allah yang disampaikan kepada Isa. Menurut Hamka, ungkapan tersebut juga berlaku untuk nabi-nabi lain sehingga tidak bisa dimaknai lebih dari panggilan pada orang-orang terdekat Tuhan. Ungkapan tersebut, dengan demikian, tidak sah untuk dijadikan basis kepercayaan bahwa Isa adalah Tuhan.

Tidak hanya itu, Hamka juga menjelaskan berbagai kesalahan lain yang lebih bersifat epistemologis. Dengan kata lain, Hamka sedang menyasar kerangka berpikir umat Kristiani dalam beberapa hal, terlebih pada kepercayaan mereka tentang trinitas Tuhan. Salah satu persoalan utama yang dijadikan sasaran kritik Hamka adalah penerjemahan Injil ke dalam berbagai bahasa tanpa ada satu Injil otentik yang bisa dijadikan patokan kebenaran terjemahan-terjemahan tersebut. Dalam skenario penerjemahan ini umat Kristiani dengan salah memahami kata sayyid yang bermakna tuan menjadi Tuhan. ${ }^{27}$ Terkait yang terakhir ini, patut dipertanyakan mengapa Hamka berasumsi bahwa kata yang digunakan oleh Injil untuk menyebut gelar Isa adalah sayyid yang notabene adalah Bahasa Arab. Pandanganpandangan polemis terhadap Barat dan Kristen semacam ini sampai hari ini pun masih ada dalam berbagai komunitas Muslim. Perdebatan polemis yang dikemukakan oleh Hamka ini jelas menunjukkan keluasan wacana dan pemahamannya tidak hanya terkait disiplin keislaman, tetapi menjangkau disiplin agama lain.

Hamka kemudian mengatakan bahwa umat Kristiani pada masa Nabi Muhammad juga berpindah agama (convert) setelah mengetahui kebenaran Islam. Orang-orang ini, menurut Hamka, berpandangan bahwa "kedatangan Rasul-Rasul, sejak Musa kemudian Almasih sampai Muhammad adalah menjalankan suatu tugas belaka, yaitu mentauhidkan Allah." ${ }^{28}$ Penafsiran Buya Hamka terhadap ayat 46-47 ini kemudian dilanjutkan dengan pembahasan mengenai hukum Islam dengan memberikan contoh beberapa persoalan tentang penerapan Hukum Islam dari masa ke masa. Seperti kisah penaklukkan Konstantinopel oleh al-Fatih, Perang Salib hingga cita-cita Hamka untuk menerapka hukum Allah yang ada di dalam Alquran secara

27 Ibid, 257.

${ }^{28}$ Ibid., $259-260$. 
penuh. ${ }^{29}$ Meski demikian, Hamka tidak menyarankan seorang Muslim untuk memaksa mereka berpindah keyakinan dan masuk agama Islam. “... namun mereka tidaklah dikerasi dan dipaksa masuk Islam. Tetapi kalau hendak tatap memegang Injil, peganglah Injil yang betul, hilangkanlah pengaruh lain dan tafsiran lain yang dimasukkan ke dalam Injil oleh keputusan Pendeta." 30

Penafsiran serupa juga dilakukan oleh Bisri Mustofa dalam Tafsir al-Ibriz yang mengatakan bahwa setelah Allah menurunkan Taurat kepada Nabi-Nabi Bani Israil, Allah kemudian mengutus Nabi Isa dan menurunkan Kitab Injil yang di dalamnya memberikan pembenaran tentang dirutunkannya Taurat. Serupa dengan kitab Taurat, kitab Injil yang diturunkan kepada Nabi Isa juga berisikan petunjuk-petunjuk dan juga cahaya serta membenarkan tentang hukum-hukum syariat yang berlaku di dalam Taurat. Bisri Mustafa mengatakan bahwa setelah Injil diturunkan kepada Nabi Isa, kitab selanjutnya yang diturunkan yaitu Kitab Alquran kepada Nabi Muhammad sebagai sebuah kitab yang membawa kebenaran. Sama seperti sebelumnya di dalam Alquran juga membenarkan tentang adanya kitab terdahulu yaitu Taurat dan Injil. ${ }^{31}$

Pandangan Bisri Mustofa tersebut diatas senada dengan apa yang disampaikan oleh Buya Hamka bahwa dari setiap agama samawi yang dibedakan adalah syariatnya, sementara pokok dan inti dari ajaran agamanya adalah satu, yaitu tentang tauhid.

Jika Hamka terkesan cukup keras dan tegas terhadap Kristen dalam narasi-narasi di atas, ini tidak berlaku pada Yahudi. Sepanjang menafsirkan tiga ayat di atas, Hamka hanya mengutip komunitaskomunitas Yahudi yang hidup pada masa Nabi Muhammad dan berdialog dengan beliau. ${ }^{32}$ Kaum Yahudi yang dijelaskan di sini tidak digambarkan sebagai sosok dengan berbagai karakter dan aspek yang bertentangan dengan Islam. Namun, ini bisa dipahami sebagai peniadaan (ignorance) terhadap mereka. Bagaimanapun, Hamka hidup dalam komunitas yang memungkinkannya lebih banyak bersinggungan dengan agama Kristen dan pemeluknya daripada bertemu dan bersinggungan dengan pemeluk agama Yahudi.

\footnotetext{
${ }^{29}$ Ibid., $261-264$.

30 Ibid., 260.

31 Bisri Mustafa, Tafsì al-Ibriz li Ma'rifat Tafsì al-Qur'ān al-'Azìz (Rembang: Menara Kudus, t.t), 294.

32 Ibid. Vol. 6, 255-258.
} 
Sikap tegas dan keras Hamka terhadap orang Kristen ini konsisten dengan fatwa MUI dalam masa kepemimpinannya. Dalam fatwa tersebut dinyatakan bahwa umat Islam diharamkan mengikuti perayaan natal yang dituangkan dalam 3 poin yaitu: 1) Perayaan Natal di Indonesia meskipun tujuannya merayakan dan menghormati Nabi Isa, akan tetapi Natal itu tidak dapat dipisahkan dari soal-soal yang diterangkan di atas. 2) Mengikuti upacara Natal bersama bagi umat Islam hukumnya haram. 3) Agar umat Islam tidak terjerumus kepada syubhat dan larangan Allah dianjurkan untuk tidak mengikuti kegiatan-kegiatan Natal. ${ }^{33}$

Fatwa ini kemudian didapati berseberangan dengan pandangan Menteri Agama pada masa itu, Alamsyah Ratu Perwiranegara. Perdebatan kemudian terjadi cukup hebat di antara kedua pihak ini. Mundurnya Hamka dari MUI juga diduga berkaitan dengan perdebatan ini. ${ }^{34}$

\section{Penutup}

Dari penjelasan di atas dapat dilihat bahwa Hamka menunjukkan sikap yang tidak konsisten dalam penafsiran ayat-ayat tentang keberagaman. Sikap tersebut bergantung pada konteks di mana keberagaman itu terjadi. Dalam konteks kemanusiaan secara umum, Hamka cenderung bersikap lunak dalam menyikapi keberagaman. Ia bahkan menyarankan untuk saling mempelajari kelebihan masingmasing, bukan mengungkap kekurangan dan perbedaan yang hanya akan menghadirkan konflik. Namun ketika keberagaman tersebut masuk dalam konteks agama, Hamka cenderung bersikap defensif, bahkan menyerang walaupun tidak sampai menyerukan perlawanan. Sikap Hamka terhadap Kristen dengan jelas mencerminkan ini. Minimnya singgungan terhadap Yahudi bisa saja dianggap sebagai peniadaan terhadapnya, yang merupakan penyikapan yang justeru lebih serius.

Dalam menjelaskan semua itu, Hamka tetap dalam karakternya yang dikenal oleh banyak sarjana pengkaji tafsir Indonesia. Intensnya singgungan terhadap konteks sosio-politik yang dihadapi terlihat dalam hampir setiap bagian tafsirnya terhadap ayat-ayat yang berkaitan

${ }^{33}$ Fatwa MUI Tentang Perayaan Natal bersama Tanggal 7 Maret 1981, hlm. 284, diakses pada tanggal 15 April 2020 pukul 20.30 di halaman http://mui.or.id/wpcontent/uploads/files/fatwa/05.-Perayaan-Natal-Bersama.pdf

34 Rusydi, Martabat dan Pribadi Buya Prof. Dr, Hamka, 219-220 
dengan kemajemukan, baik kemajemukan secara umum, maupun kemajemukan agama.

\section{Daftar Pustaka}

Alfian. "Hamka dan Anaknya" dalam Solichin Salam (dkk.)(ed.), KenangKenagnan 70 Tabun Buya Hamka. Jakarta: Yayasan Nurul Islam. 1978.

Aliviyah, Avif. "Metode Penafsiran Buya Hamka dalam Tafsir al-Azhar," dalam Jurnal Ilmiab Ilmu Ushuluddin. Vol. 15, No.1 (2016).

Amal, Taufik Adnan. Rekonstruksi Sejarah Al-Qur'an. Jakarta: Pustaka alFabets, 2005.

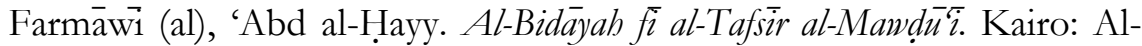
Hadāah al-'Arabiyah, 1997.

Federspiel, Howard M. Kajian-kajian al-Qur'an di Indonesia. Bandung: Mizan. 1996.

Hamka. "Nama Saya: Hamka" dalam Nasir Tamara (dkk.) (ed.), Hamka di Mata Hati Umat. Jakarta: Sinar Harapan, 1983. . Tafsir al-A₹̧har. Jakarta: Pustaka Panjimas, 1982.

Hamka, Irfan. Ayah. Jakarta: Republika, 2016.

Hidayati, Husnul. "Metodologi Tafsir Kontekstual Al-Azhar Karya Buya Hamka," dalam El-Umdah Jurnal Ilmu Alquran dan Tafsir, Vol. 1, No. 1 (2018).

'Imārah, Muhammad. Islam dan Pluralitas: Perbedaan dan Kemajemukan dalam Bingkai Persatuan, terj. Abdul Hayyie al-Kattanie. Jakarta: Gema Insani Press, 1997.

Muklis. Inklusifisme Tafsir al-Azhar. Mataram: IAIN Mataram Press, 2004.

Mustafa, Bisti. Tafsir al-Ibriz li Ma'rifat Tafsir al-Qur'an al-'Ažiz. Kudus: Menara Kudus. t.t.

Nurrohman. "Islam dan Kemajemukan di Indonesia: Upaya Menjadikan Nilai-Nilai Yang Menjunjung Tinggi Kemajemukan Dalam Islam Sebagai Kekuatan Positif Bagi Perkembangan Demokrasi," dalam Asy-Syariah. Vol. 17 No. 3 (2015).

Rusydi. Martabat dan Pribadi Buya Prof. Dr. Hamka. Jakarta: Pustaka Panjimas, 1983.

Said, Hasani Ahmad. "Mengenal Tafsir Nusantara: Melacak Mata Rantai Tafsir Dari Indonesia, Malaysia, Thailand, Singapura Hingga Brunei Darussalam.” dalam Refleksi. Vol. 16, No. 2 (2017).

Tim Penerjemah Alquran Depag RI, Alquran dan Terjemahnya. Jakarta: Yayasan Penyelenggara Penerjemah/penafsiran Alquran, Depag RI, 1975.

Umar, Ratnah. "Tafsir al-Azhar (Metode dan Corak penafsirannya)." Dalam al-Asas, Vol. III, No. 1 (2015). 